obliged to implement a cabinet decision to impose them.

His term of office must be credited with one major reform: the abolition, in 1986, of the remaining restrictions on the autonomy of the universities to decide who they could admit as students. (Racial criteria on admissions were imposed by the government in 1959, and remained in place in some fields of study until 1986).

As a consequence, black students now comprise between 19 per cent and 28 per cent of the student body at the Englishspeaking campuses, whereas in the country as a whole, 84 per cent of the population but only 40 per cent of university students are black. Black students comprise 9 per cent of the student body at the dual-language University of Port Elizabeth. At the Afrikaans universities, these figures are lower, ranging from 5 per cent at Stellenbosch to only 0.3 per cent at Pretoria.

The universities at present claim 15 per cent of the education budget. While not ruling out the possibility of a modest increase in this figure, de Klerk has prescribed rationalization as the key to solving their financial problems, and it is in this context that he abolished statutory racial admissions criteria. Yet he has held back from forcing rationalization upon the universities, stating that he would rather it were self-imposed.

An obvious possibility would be to downgrade the status of universities with few postgraduate students to that of American-style colleges. This is a measure unlikely to be willingly self-imposed by these institutions and one which would be politically sensitive: most of the likely candidates are homeland universities set up for each ethnic group as part of the masterplan of grand apartheid. As he lacks the political courage to implement the logical consequences of rationalization himself, de Klerk has resorted to squeezing the universities financially in the hope that they will implement it themselves.

But de Klerk's brand of conservative pragmatism, in the context of South African politics, is not the worst possible prospect.

$\mathrm{He}$ has at least displayed that he has some respect for constitutional government, a notion that appears almost entirely alien to President Botha. In addition, he has a renowned distrust of the "securocrats" who surround the state president, and into whose hands much of the country's administration has passed in recent years. If technocrats such as Roux Venter are to replace the major-generals as the mandarins of the new regime, there may be cause for cautious optimism. Either a reduced majority for the National Party in September, or a decline in his own support within the party, could cause de Klerk to bend his pragmatism in a more enlightened direction.

Michael Cherry

\title{
Survivors return to the wild
}

\section{San Franclsco}

IN the first major attempt to determine the effect of the Alaskan oil spill on marine mammals, 28 sea otters tagged with miniature radio-transmitters were released back into Prince William Sound late last month. The otters had been rescued from the oil-polluted sound after the Exxon tanker Valdez struck a reef in March, spilling 10 million gallons of crude oil into the water.

Biologists at the US Fish and Wildlife Service (USFWS) hope to learn whether the otters can return to the waters where they were rescued and whether they can survive in the wild after being in captivity for as long as four months. The answers will help the service to decide what to do with the 170 sea otters still awaiting release. Over the longer term, the study will assess whether food sources have been contaminated and will compare the survival rate of the released mammals to that of other radio-tagged otters that remained in the wild throughout the spill.

Most of the otters released last week carried surgically implanted radio-transmitters designed to broadcast signals for 30 months. The otters -14 females and 14 males - were set free in clean areas of the sound's eastern section. Much of the crude oil has moved out of the sound or congealed into easily avoidable clumps. "I don't think there have been any new mortalities recently", said Tony DeGange, a wildlife biologist from the US Fish and Wildlife Service (USFWS) in Anchorage. "I wouldn't say it's over, but certainly the oiling from heavy oil is over." According to USWF figures released on 3 August, 28,734 birds, 905 otters and 122 bald eagles died as a result of the spill. Thirty four otters and 671 birds, including 15 eagles, have been released back into the wild after treatment to remove oil.

Scientists are now hurrying to gather the data needed to assess the total damage caused to the environment before winter arrives and field work becomes impossible. An effort is being made to examine any national resources that may have been affected - fish, mammals, birds and any other wildlife. No conclusions will be drawn until autumn or winter by which time researchers will have had a chance to compare new data to previous studies.

Alaska's huge fisheries industry suffered immediate damage in both Prince William Sound and around Kodiak Island to the south-west. The herring-roe harvest in the sound, which totalled $\$ 12.2$ million last year, was lost completely as officials closed the season for fear of contamination. The salmon industry suffered an even worse fate, with two of 11 salmon districts closed entirely because of heavy oil in Prince William Sound, site of a \$76-million harvest last year. Almost the entire season was lost around Kodiak Island, where salmon fishermen netted $\$ 94.4$ million in sales last year.

News of the otter release came as a leaked internal memorandum from the general manager of the clean-up operation at Exxon drew an angry response from some environmentalists and state officials. The memorandum revealed that the company planned to end clean-up operations for the winter by mid-September. Exxon employs nearly 11,000 primary and support workers in its clean-up operation, which covers vast areas of sea and about 728 miles of coastline.

Exxon was quick to explain last week that the memorandum did not mark a deviation from the clean-up plan formulated last May, but simply a gradual withdrawal before winter arrives. Exxon claims it will complete the clean-up by mid-September. Its workers have successfully treated some 600 miles of affected shoreline, often in remote and rocky areas accessible only by boat or helicopter.

Robert Buderi

\section{IMAGE UNAVAILABLE FOR COPYRIGHT REASONS}

